\title{
A Prospective Study of Glomerular Filtration Rate and Arterial Blood Pressure in Insulin-Dependent Diabetics with Diabetic Nephropathy
}

\author{
H.-H. Parving, U. M. Smidt, B. Friisberg, V. Bonnevie-Nielsen, and A. R. Andersen \\ Steno Memorial Hospital, Gentofte, and Department of Clinical Physiology and Department of Medicine C, Bispebjerg Hospital, \\ Copenhagen, Denmark
}

Summary. Glomerular filtration rate (GFR, single bolus ${ }^{51} \mathrm{Cr}$-EDTA technique), serum creatinine, proteinuria and arterial blood pressure have been measured prospectively in 14 young onset insulin-dependent diabetics selected by of persistent proteinuria ( $>$ $0.5 \mathrm{~g} /$ day) secondary to diabetic nephropathy. Twelve of the 14 patients had normal serum creatinine levels. None of the patients received antihypertensive treatment. During the mean observation period of 26 months (range 23 to 33 months) GFR decreased from 107 to $87 \mathrm{ml} / \mathrm{min} / 1.73 \mathrm{~m}^{2}$ ( $\mathrm{p}<$ 0.001 ), serum creatinine remained unchanged: 107 and $112 / \mu \mathrm{mol} / 1$ (NS), proteinuria increased from 1.8 to $3.3 \mathrm{~g} /$ day $(\mathrm{p}<0.001)$ and arterial blood pressure rose from $132 / 88$ to $153 / 101 \mathrm{mmHg}(\mathrm{p}<0.001$ ). Glomerular filtration rate decreased linearly with time (slope $=-0.75, \mathrm{r}=0.99, \mathrm{p}<0.001$ ) by a mean of $0.75 \mathrm{ml} / \mathrm{min} /$ month (range 0.1 to $1.5 \mathrm{ml} /$ $\mathrm{min} / \mathrm{month}$ ). The decrease in GFR did not correlate with sex, age at onset, duration of diabetes, arterial blood pressure, proteinuria, insulin requirement, postprandial blood glucose or the initial GFR, but numbers were small. The decline in GFR in each individual was constant, but varied considerably between patients. Increase in arterial blood pressure to a hypertensive level is an early feature of diabetic nephropathy in young insulin-dependent diabetics.

Key words: Diabetic nephropathy, glomerular filtration rate, hypertension, proteinuria, insulin-dependent diabetes, serum creatinine.

Renal failure due to diabetic nephropathy is the single major cause of death (about $30 \%$ ) in juvenileonset insulin-dependent diabetics (IDD) $[1,2,3]$. Approximately $40 \%$ of IDD patients develop proteinuria $[1,2,3]$, the average time being 19 years (range 4 to 41 years) from the time of diagnosis [4].
On average death takes place six years after the start of persistent proteinuria, but the range is wide ( 2 to 32 years) [4]. The factors responsible for this highly variable course of diabetic nephropathy are not known. Watkins et al. [5] demonstrated that diabetics with heavy proteinuria (more than $3 \mathrm{~g} / 24$ hours) and marked renal histological changes have the worst prognosis. Recently, Mogensen [6] demonstrated that the rate of decline in glomerular filtration rate (GFR) in diabetic nephropathy, observed during a mean period of 34 months, was positively correlated with diastolic blood pressure measured at the end of the observation period.

The aim of the present prospective study of GFR, serum creatinine, urinary protein excretion and arterial blood pressure (BP) was to elucidate some aspects of the initial part of the natural history of diabetic nephropathy in IDD. Secondly, we wanted to evaluate the relationship between the decline in GFR and sex, age at diagnosis of diabetes, interval between diagnosis and persistent proteinuria, arterial blood pressure, insulin requirement, postprandial blood glucose, and initial GFR.

\section{Material and Methods}

Records were examined from all insulin-dependent diabetic patients with proteinuria (positive Albustix) visiting the outpatient clinic at Steno Memorial Hospital during the period between June 1976 and January 1978. All patients fulfilling the following criteria were asked to participate in the present prospective study: persistent proteinuria (see below), age less than 41 years, onset of insulin-dependent diabetes before 31 years, serum creatinine less than $150 \mu \mathrm{mol} / 1$, no antihypertensive treatment including diuretics, and no blindness. Two females and one male did not want to participate. One female dropped out during the investigation after moving away. The remaining 14 patients ( 4 females and 10 males), all fully informed before giving their consent, were investigated (Table 1).

All patients were ketosis-prone. None of the patients were taking drugs, except number 1 who was receiving phenytoin $400 \mathrm{mg} /$ day, for epilepsy. 
Table 1. Clinical data of fourteen insulin-dependent diabetics with persistent proteinuria

\begin{tabular}{|c|c|c|c|c|c|c|c|}
\hline Patient & Sex & $\begin{array}{l}\text { Age } \\
\text { (years) }\end{array}$ & $\begin{array}{l}\text { Body } \\
\text { weight } \\
\text { (\% of ideal) }\end{array}$ & $\begin{array}{l}\text { Duration of } \\
\text { diabetes } \\
\text { (years) }\end{array}$ & $\begin{array}{l}\begin{array}{l}\text { Insulin } \\
\text { dose }^{\mathrm{a}}\end{array} \\
\text { (units } / \mathrm{kg} / \text { day) }\end{array}$ & $\begin{array}{l}\text { Retino- } \\
\text { pathy }\end{array}$ & $\begin{array}{l}\text { Interval between } \\
\text { persistent proteinuria } \\
\text { and first investigation } \\
\text { (months) }\end{array}$ \\
\hline 1 & $F$ & 39 & 105 & 25 & 0.73 & $P$ & 12 \\
\hline 2 & $F$ & 19 & 105 & 6 & 0.70 & nil & 6 \\
\hline 3 & $\mathrm{~F}$ & 31 & 93 & 21 & 0.75 & $\mathrm{P}$ & 14 \\
\hline 4 & $\mathbf{M}$ & 34 & 100 & 12 & 0.44 & B & 6 \\
\hline 5 & $\mathbf{M}$ & 26 & 85 & 15 & 0.71 & $P$ & 15 \\
\hline 6 & M & 35 & 100 & 6 & 0.28 & nil & 6 \\
\hline 7 & $\mathbf{M}$ & 40 & 97 & 18 & 0.58 & B & 6 \\
\hline 8 & $\mathbf{M}$ & 40 & 94 & 21 & 0.61 & $\mathbf{P}$ & 36 \\
\hline 9 & $\mathrm{~F}$ & 20 & 108 & 16 & 0.67 & $\mathrm{P}$ & 6 \\
\hline 10 & $M$ & 28 & 87 & 17 & 1.30 & B & 24 \\
\hline 11 & $M$ & 24 & 89 & 12 & 0.69 & $\mathrm{P}$ & 9 \\
\hline 12 & $\mathbf{M}$ & 28 & 97 & 27 & 0.62 & $\mathrm{P}$ & 40 \\
\hline 13 & $\mathrm{M}$ & 34 & 97 & 22 & 0.83 & $\mathrm{P}$ & 12 \\
\hline 14 & M & 36 & 106 & 13 & 0.73 & $\mathrm{~B}$ & 5 \\
\hline mean & & 31 & 97 & 17 & 0.69 & & 14 \\
\hline$\pm \mathrm{SEM}$ & & 2 & 2 & 2 & 0.06 & & 3 \\
\hline
\end{tabular}

${ }^{a}$ Before persistent proteinuria and after 5 years duration of diabetes; ${ }^{\mathrm{b}} \mathrm{P}=$ proliferative, $\mathrm{B}=$ background

Table 2. Linear regression analyses between glomerular filtration rate and time in insulin-dependent diabetics with persistent proteinuria

\begin{tabular}{rllll}
\hline Patient & $\begin{array}{l}\text { No. of GFR } \\
\text { observations }\end{array}$ & $\begin{array}{l}\text { Fall rate of } \\
\text { GFR } \\
\text { min/month) }\end{array}$ & $\begin{array}{l}\text { Correlation } \\
\text { coefficient of } \\
\text { regression line }\end{array}$ & $\mathrm{p}$ \\
\hline 1 & 7 & 0.53 & 0.75 & $<0.05$ \\
2 & 6 & 0.71 & 0.85 & $<0.01$ \\
3 & 6 & 0.82 & 0.85 & $<0.01$ \\
4 & 6 & 0.49 & 0.94 & $<0.001$ \\
5 & 4 & 0.77 & 0.93 & $<0.01$ \\
6 & 6 & 0.90 & 0.82 & $<0.05$ \\
7 & 5 & 0.70 & 0.93 & $<0.01$ \\
8 & 5 & 0.32 & 0.82 & $<0.05$ \\
9 & 4 & 1.46 & 0.97 & $<0.01$ \\
10 & 4 & 0.13 & 0.35 & $<\mathrm{NS}$ \\
11 & 4 & 0.80 & 0.91 & $<0.01$ \\
12 & 4 & 0.61 & 0.97 & $<0.01$ \\
13 & 4 & 1.10 & 0.83 & $<0.05$ \\
14 & 4 & 0.96 & 0.95 & $<0.01$ \\
\hline
\end{tabular}

a Calculated from the slope of the regression line

Persistent proteinuria was defined as urinary protein excretion of more than $0.5 \mathrm{~g} / 24 \mathrm{~h}$ on 4 consecutive visits to the outpatient clinic (interval between visits 8 to 12 weeks).

Diabetic nephropathy was diagnosed clinically if the following criteria were fulfilled: persistent proteinuria, duration of IDD of more than 10 years, presence of diabetic retinopathy and no clini$\mathrm{cal}$ or laboratory evidence of disease of the kidneys or the renal tract other than diabetic nephropathy. Three patients (2, 6 and 10) did not fulfill all the above mentioned criteria. A kidney biopsy was therefore performed and in all cases slight to moderate changes of diabetic nephropathy were found.
All investigations were made on the same day between $0900 \mathrm{~b}$ and $1300 \mathrm{~h}$. Patients had their normal breakfast and morning insulin before the investigations, which were carried out with the patients resting in the supine position. The investigations were performed 4 to 7 times in each patient during an investigation period ranging from 23 to 33 months.

GFR was measured after a single IV injection of ${ }^{51} \mathrm{Cr}$-EDTA at $0900 \mathrm{~h}$ by studying the plasma disappearance for $4 \mathrm{~h}$ [7]. The mean intra-individual coefficient of variation for GFR was $4.1 \%$.

Serum creatinine concentration was measured on a Greiner Selective Analyzer II, using a modified Jaffé's reaction. The reaction time was $6.4 \mathrm{~min}$. To reduce the interference from pseudocreatinines the reading during the first $1.2 \mathrm{~min}$ was subtracted. The mean intra-individual coefficient of variation for serum creatinine determination was 4 to $7 \%$. Blood glucose was measured at $0900 \mathrm{~h}$ by autoanalyser, using a glucose oxidase method.

Blood pressure was measured three times in the supine position during each investigation. Diastolic blood pressure was recorded at the disappearance of the Korotkoff sounds (phase 5).

Body weight was measured at each investigation. Daily urinary protein excretion was measured according to Tsuchiya [8] at each visit to the outpatient clinic.

The patients visited the clinic every 2 to 4 months during the investigation period. At each visit postprandial blood glucose and glucosuria were measured.

Wilcoxon's non-parametric test for paired comparison was used for statistical analysis. Mean values are given with standard error of mean (SEM).

\section{Results}

A gradual but significant decline in GFR was demonstrated in all patients, except one (Table 2). The decline in GFR varied considerably from one patient to another (range 0.1 to $1.5 \mathrm{ml} / \mathrm{min} /$ month, mean $0.75 \mathrm{ml} / \mathrm{min} / \mathrm{month}$, Table 2 ). Over the course of the 
Table 3. Course of glomerular filtration rate, serum creatinine, proteinuria and arterial blood pressure in insulin-dependent diabetics with persistent proteinuria

\begin{tabular}{|c|c|c|c|c|c|c|c|c|c|c|c|}
\hline \multirow[t]{2}{*}{$\begin{array}{l}\text { Subject } \\
\text { no. }\end{array}$} & \multirow[t]{2}{*}{$\begin{array}{l}\text { Period between } \\
\text { first and last } \\
\text { investigation } \\
\text { (months) }\end{array}$} & \multirow[t]{2}{*}{$\begin{array}{l}\text { Number of } \\
\text { investiga- } \\
\text { tions }\end{array}$} & GFR & $\left(1.73 \mathrm{~m}^{2}\right)$ & \multicolumn{2}{|c|}{$\begin{array}{l}\text { Serum } \\
\text { creatinine }\end{array}$} & \multicolumn{2}{|c|}{$\begin{array}{l}\text { Protein- } \\
\text { uria }\end{array}$} & $\begin{array}{l}\text { Blood } \\
\text { pressure } \\
(\mathrm{mmHg})\end{array}$ & & \multirow[t]{2}{*}{$\begin{array}{l}\begin{array}{l}\text { Blood } \\
\text { glucose }^{a}\end{array} \\
(\mathrm{mmol} / \mathrm{l})\end{array}$} \\
\hline & & & $\bar{F}$ & $\mathrm{~L}$ & $\mathrm{~F}$ & $\mathrm{~L}$ & $\bar{F}$ & $\mathrm{~L}$ & $\bar{F}$ & $\mathrm{~L}$ & \\
\hline 1 & 29 & 7 & 116 & 97 & 84 & 97 & 2.4 & 4.5 & $135 / 82$ & $145 / 81$ & $14.7 \pm 0.7(42)$ \\
\hline 2 & 31 & 6 & 119 & 101 & 99 & 103 & 1.2 & 3.2 & $120 / 86$ & $128 / 100$ & $15.1 \pm 0.9(21)$ \\
\hline 3 & 29 & 6 & 111 & 88 & 90 & 96 & 0.5 & 1.4 & $128 / 88$ & $152 / 94$ & $7.6 \pm 0.5(18)$ \\
\hline 4 & 33 & 6 & 108 & 93 & 101 & 101 & 0.6 & 1.7 & $136 / 92$ & $164 / 98$ & $11.5 \pm 0.9(17)$ \\
\hline 5 & 27 & 4 & 105 & 82 & 122 & 100 & 1.1 & 2.8 & $120 / 60$ & $145 / 90$ & $7.2 \pm 1.6(13)$ \\
\hline 6 & 25 & 6 & 90 & 70 & 117 & 119 & 1.6 & 1.7 & $128 / 98$ & $152 / 116$ & $14.0 \pm 0.8(17)$ \\
\hline 7 & 24 & 5 & 105 & 88 & 119 & 126 & 0.8 & 1.3 & $135 / 80$ & $168 / 104$ & $8.6 \pm 1.2(14)$ \\
\hline 8 & 27 & 5 & 76 & 66 & 129 & 139 & 1.8 & 4.3 & $142 / 92$ & $185 / 105$ & $12.6 \pm 0.9(17)$ \\
\hline 9 & 23 & 4 & 115 & 85 & 98 & 85 & 2.1 & 0.8 & $135 / 98$ & $142 / 106$ & $9.2 \pm 1.1(14)$ \\
\hline 10 & 24 & 4 & 127 & 119 & 99 & 86 & 4.7 & 11.0 & $140 / 96$ & $172 / 114$ & $13.5 \pm 1.5$ \\
\hline 11 & 25 & 4 & 121 & 101 & 94 & 119 & 0.7 & 2.3 & $128 / 84$ & $135 / 108$ & $16.0 \pm 1.4(14)$ \\
\hline 12 & 23 & 4 & 64 & 49 & 146 & 175 & 4.0 & 3.8 & $140 / 94$ & $168 / 100$ & $9.6 \pm 2.3$ \\
\hline 13 & 23 & 4 & 113 & 83 & 98 & 109 & 2.4 & 5.0 & $130 / 98$ & $146 / 112$ & $12.4 \pm 0.8$ \\
\hline 14 & 24 & 4 & 126 & 99 & 109 & 116 & 1.2 & 2.0 & $138 / 90$ & $134 / 80$ & $12.5 \pm 0.9(14)$ \\
\hline Mean & 26 & 5 & 107 & 87 & 107 & 112 & 1.8 & 3.3 & $132 / 88$ & $153 / 101$ & 11.8 \\
\hline$\pm \mathrm{SEM}$ & 1 & 0.3 & 5 & 5 & 5 & 6 & 0.3 & 0.7 & $2 / 3$ & $4 / 3$ & 0.8 \\
\hline $\mathbf{P}$ & & & \multicolumn{2}{|c|}{$<0.001$} & \multicolumn{2}{|c|}{ NS } & \multicolumn{2}{|c|}{$<0.01$} & \multicolumn{2}{|c|}{$<0.01$} & \\
\hline
\end{tabular}

$\mathrm{F}=$ first investigation, $\mathrm{L}=$ last investigation

a Average postprandial blood glucose during the whole observation period, number of determinations indicated in bracket

study GFR declined from $107 \pm 5 \mathrm{ml} / \mathrm{min} / 1.73 \mathrm{~m}^{2}$ to a final value of $87 \pm 5 \mathrm{ml} / \mathrm{min} / 1.73 \mathrm{~m}^{2}, \mathrm{p}<0.001$ (Table 3).

The individual values measured at the first and the last investigation are given in Table 3. Serum creatinine did not change significantly during the observation period: $107 \pm 5 \mu \mathrm{mol} / 1$ at the start compared with a final value of $112 \pm 6 \mu \mathrm{mol} / 1$. No significant change in body weight occurred during the investigation. Proteinuria increased from $1.8 \pm 0.3 \mathrm{~g} /$ $24 \mathrm{~h}$ to $3.3 \pm 0.7 \mathrm{~g} / 24 \mathrm{~h}, \mathrm{p}<0.01$. Except for patients 1 and 14, the rest showed an increase in arterial blood pressure during the study, from mean 132/88 $\pm 2 / 3 \mathrm{mmHg}$, at the first determination to $153 / 101$ $\pm 4 / 3 \mathrm{mmHg}$, at the last recording, $p<0.001$.

Figure 1 shows the overall trends in measured variables during the first 23 months observation. Compilation of GFR values from all subjects showed a straight-line correlation with time, slope of regression line $=-0.75, \mathrm{r}=0.99, \mathrm{p}<0.001$. The increase in systolic and diastolic blood pressure was more pronounced during the second year compared to the first year. Six of the patients had a gradual increase in diastolic blood pressure over the whole investigation period. A more accelerated increase was recorded in another 6 patients, $\triangle$ diastolic BP $>$ $1.5 \mathrm{mmHg} /$ month during a 6 month interval.
There were no statistically significant correlations between the rate of fall in GFR and sex, age at diagnosis of diabetes, interval between diagnosis and persistent proteinuria, proteinuria, initial GFR level, systolic or diastolic blood pressure, insulin requirement, or postprandial blood glucose.

Postprandial blood glucose and insulin dose remained unchanged during the investigation period.

\section{Discussion}

Our prospective study in young female and male insulin-dependent diabetics with diabetic nephropathy demonstrated that the rate of fall of GFR varies considerably from one patient to another $(\triangle$ GFR 0.1 to $1.5 \mathrm{ml} / \mathrm{min} / \mathrm{month}$ ). Mogensen [6] found an even greater variation in the progression of this disease in 10 young male insulin-dependent diabetics, with a fall in GFR of 0.2 to $2.1 \mathrm{ml} / \mathrm{min} / \mathrm{month}$. Recently, Jones et al. [12] demonstrated that the deterioration of renal function, measured by the inverse of serum creatinine $(\mathrm{l} / \mathrm{Cr})$ method, varies markedly in young female and male patients with advanced diabetic nephropathy (serum-creatinine $>200 \mu \mathrm{mol} / \mathrm{l}$ ). Epidemiological studies of insulindependent diabetics with diabetic nephropathy have 

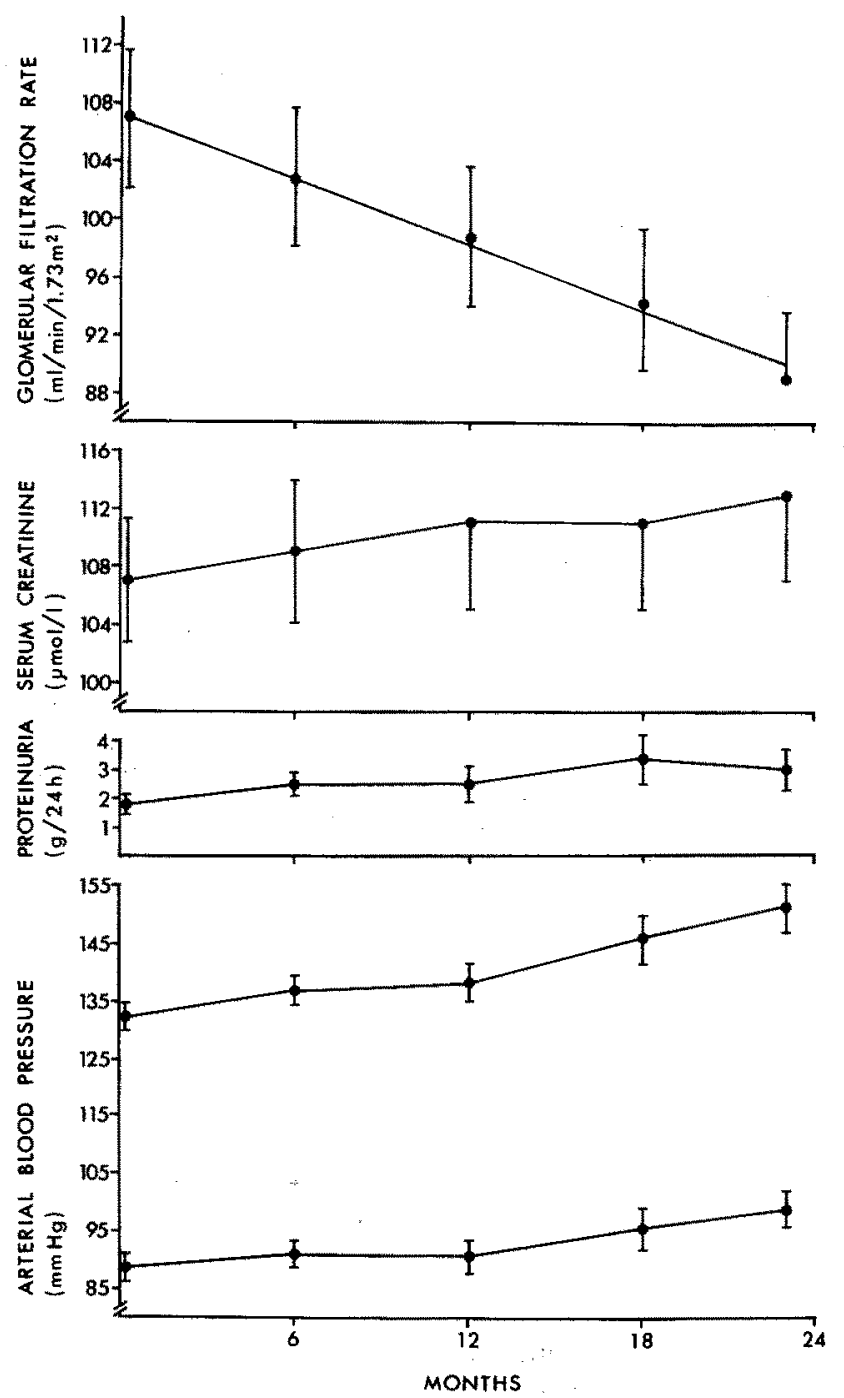

Fig. 1. The average course of glomerular filtration rate, serum creatinine level, proteinuria, systolic and diastolic blood pressure during the initial 23 months investigation period. Data compiled from all 14 insulin-dependent diabetics with diabetic nephropathy. Vertical bars indicate SEM

shown that the time interval from persistent proteinuria until death from uraemia ranges from few years to 32 years [4]. Thus the progression of diabetic nephropathy in juvenile-onset insulin-dependent diabetics shows a remarkable variation.

Serum creatinine did not change significantly during the 26 months observation period in our 12 patients with serum creatinine and GFR within the normal range, in spite of a decrease in GFR of $0.78 \mathrm{ml} / \mathrm{min} / \mathrm{month}$. The following factors might contribute to this discrepancy: assay interference from so called pseudocreatinines [9], variation in tubular creatinine secretion, and diminished urinary creatinine excretion. It is possible that tubular creatinine secretion varies in IDD patients, since metabolic control influences renal tubular function [10]. We did not measure urinary creatinine excretion, but calculation of the glomerular filtration of creatinine from GFR $\times$ serum creatinine [11], suggested a significant reduction with progression of diabetic nephropathy.

Even though the progression of renal failure varies considerably, the rate of fall of GFR in each individual patient is rather constant, as indicated by our finding of a straightline correlation between GFR and time. Jones et al. [12] demonstrated that the inverse of the serum creatinine concentration showed a straight-line correlation with time in each individual patient with advanced diabetic nephropathy (serum creatinine $>200 \mu \mathrm{mol} / \mathrm{l}$ ). The same finding of a constant progression in kidney function in individual patients has been obtained in various other renal diseases [13].

The factors responsible for the progression of the diabetic nephropathy are not known. In our study of a small number of patients we found no correlation between the fall rate in GFR and sex, age at diagnosis of diabetes, interval between diagnosis and persistent proteinuria, initial GFR level, systolic or diastolic blood pressure, increase in blood pressure during the investigation, insulin requirement, or postprandial blood glucose concentration. Jones et al. [12] obtained the same negative results in their patients with more advanced diabetic nephropathy. By contrast, Mogensen [6] found, in seven patients observed for nearly 3 years, a significant positive correlation between the fall rate in GFR and diastolic blood pressure measured at the end of the 3 year observation period. Unfortunately, information on blood pressure during the investigation period is not available in the study of Mogensen. Watkins et al. [5] have shown that diabetics with proteinuria greater than $3 \mathrm{~g} / 24 \mathrm{~h}$ and severe histological diabetic nephropathy have the worst prognosis.

A remarkable increase in arterial blood pressure occurred during the 26 months observation period, from $132 / 88 \mathrm{mmHg}$ at the initial investigation compared to $153 / 101 \mathrm{mmHg}$ at the last investigation. The blood pressure increased in 12 of our patients and remained unchanged in the remaining 2 patients. Mogensen [6] found an average blood pressure of $159 / 101 \mathrm{mmHg}$ in young male IDD patients with diabetic nephropathy. The mean GFR was $93 \mathrm{ml} /$ $\mathrm{min} / 1.73 \mathrm{~m}^{2}$ in Mogensen's study, and $89 \mathrm{ml} / \mathrm{min} /$ $1.73 \mathrm{~m}^{2}$ in the present study. These findings lead to the conclusion that elevation of arterial blood pressure is an early feature of diabetic nephropathy in young insulin-dependent diabetics. 
Recently, the effect of haemodynamic changes on diabetic nephropathy has been elucidated. Steffes et al. [14] demonstrated that unilateral nephrectomy in diabetic rats accelerates in development of diabetic glomerulopathy, probably due to elevated intraglomerular pressure. Furthermore, Mauer et al. [15] found enhanced development of diabetic nephropathy in rats with two-kidney Goldblatt hypertension and streptozotocin induced diabetes. Berkman et al. [16] have reported a unique patient with unilateral renal artery stenosis and diabetes. The stenotic kidney had only ischaemic changes while the contralateral kidney demonstrated advanced diabetic nephropathy. Finally, Mogensen [17] has demonstrated that effective antihypertensive treatment in 2 patients with diabetic nephropathy reduced the fall rate in GFR. These findings suggest that an early and effective treatment of the arterial blood pressure elevation in diabetic nephropathy might postpone endstage renal failure.

Acknowledgement. This study was supported by grants from King Christian X's Foundation, Landsforeningen for sukkersyge, and the Danish Medical Research Council.

\section{References}

1. Knowles HC (1974) Magnitude of the renal failure problem in diabetes. Kidney Int [Suppl 1] 6: 2-7

2. Cameron JS, Ireland JT, Watkins PJ (1975) The kidney and renal tract. In: Keen $\mathrm{H}$, Jarrett $\mathrm{J}$ (eds) Complications of diabetes. Edward Arnold, London, p 99-150

3. Deckert T, Poulsen JE, Larsen M (1978) Prognosis of diabetics with diabetes onset before the age of thirty-one. Diabetologia 14: 363-370

4. Andersen AR, Andersen JK, Christiansen IS, Deckert T (1978) Prognosis for juvenile diabetics with nephropathy and failing renal function. Acta Med Scand 203: 131-134

5. Watkins PJ, Blainey JD, Brewer DB, Fitzgerald MG, Malins JM, O'Sullivan DJ, Pinto JA (1972) The natural history of diabetic renal disease. Q J Med 41: 437-456
6. Mogensen CE (1976) Progression of nephropathy in longterm diabetics with proteinuria and effect of initial anti-hypertensive treatment. Scand J Clin Lab Invest 36 : $383-388$

7. Bröchner-Mortensen J, Giese J, Rossing N (1969) Renal insulin clearance versus total plasma clearance of ${ }^{51} \mathrm{Cr}$-EDTA. Scand J Clin Lab Invest 23: 301-305

8. Tsuchiya (1908) Eine neue volumetrische Eiweißbestimmung mittels der Phosphorwolframsäure. Zentralbl Inn Med 29: $105-115$

9. Narayaman S, Appleton HD (1980) Creatinine: A review. Clin Chem 26: 1119-1126

10. Parving $\mathrm{H}-\mathrm{H}$, Noer I, Deckert T, Evrin P-E, Nielsen SL, Lyngsøe J, Mogensen CE, Rørth M, Svendsen PAa, TrapJensen J, Lassen NA (1976) The effect of metabolic regulation on microvascular permeability to small and large molecules in short-term juvenile diabetics. Diabetologia 12: 161-166

11. Bröchner-Mortensen J, Tougaard L, Fynboe C, Thomsen HG (1976) Individual determination of glomerular filtration rate from plasma creatinine. Scand J Clin Lab Invest 36: 389-393

12. Jones RH, Hayakawa H, Mackay JD, Parsons V, Watkins PJ (1979) Progression of diabetic nephropathy. Lancet I: 1105-1106

13. Mitch WE, Walser M, Buffington GA, Lemann J (1976) A simple method of estimating progression of chronic renal failure. Lancet II: 1326-1328

14. Steffes MW, Brown DM, Mauer SM (1978) Diabetic glomerulopathy following unilateral nephrectomy in the rat. Diabetes 27: 35-41

15. Mauer SM, Steffes MW, Azar S, Sandberg SK, Brown DM (1978) The effect of Goldblatt hypertension on development of the glomerular lesions of diabetes mellitus in the rat. Diabetes $27: 738-744$

16. Berkman J, Rifkin H (1973) Unilateral nodular diabetic glomerulosclerosis (Kimmerstiel-Wilson). Report of a case. Metabolism 22: 715-722

17. Mogensen CE (1979) Diabetes and hypertension. Lancet $\mathrm{I}$ : 388-389

Received: June 23, 1980,

and in revised form: November 20, 1980

Dr. H.-H. Parving

Department of Clinical Physiology

Bispebjerg Hospital

Bispebjerg Bakke 24

DK-2400 Copenhagen NV

Denmark 